\title{
Assessment of $\mathrm{SnFe}_{2} \mathrm{O}_{4}$ Nanoparticles for Potential Application in Theranostics: Synthesis, Characterization, In Vitro, and In Vivo Toxicity
}

\author{
Saman Sargazi ${ }^{1}$, Mohammad Reza Hajinezhad ${ }^{2}$, Abbas Rahdar ${ }^{3, *} \mathbb{1}$, Muhammad Nadeem Zafar ${ }^{4, *}$ (D), \\ Aneesa Awan ${ }^{4}$ and Francesco Baino ${ }^{5, *(D)}$ \\ 1 Cellular and Molecular Research Center, Resistant Tuberculosis Institute, \\ Zahedan University of Medical Sciences, Zahedan 98167-43463, Iran; sgz.biomed@gmail.com \\ 2 Basic Veterinary Science Department, Veterinary Medicine Faculty, University of Zabol, \\ Zabol 98613-35856, Iran; hajinezhad@gmail.com \\ 3 Department of Physics, University of Zabol, Zabol 98613-35856, Iran \\ 4 Department of Chemistry, University of Gujrat, Gujrat 50700, Pakistan; awananeesa90@gmail.com \\ 5 Institute of Materials Physics and Engineering, Department of Applied Science and Technology, \\ Politecnico di Torino, 10129 Torino, Italy \\ * Correspondence: a.rahdar@uoz.ac.ir (A.R.); znadeempk@gmail.com (M.N.Z.); francesco.baino@polito.it (F.B.)
}

Citation: Sargazi, S.; Hajinezhad, M.R.; Rahdar, A.; Zafar, M.N.; Awan, A.; Baino, F. Assessment of $\mathrm{SnFe}_{2} \mathrm{O}_{4}$ Nanoparticles for Potential Application in Theranostics: Synthesis, Characterization, In Vitro, and In Vivo Toxicity. Materials 2021, 14, 825. https://doi.org/10.3390/ ma14040825

Academic Editor: Ana Alcudia

Received: 6 January 2021

Accepted: 1 February 2021

Published: 9 February 2021

Publisher's Note: MDPI stays neutral with regard to jurisdictional claims in published maps and institutional affiliations.

Copyright: (c) 2021 by the authors. Licensee MDPI, Basel, Switzerland. This article is an open access article distributed under the terms and conditions of the Creative Commons Attribution (CC BY) license (https:// creativecommons.org/licenses/by/ $4.0 /)$.

\begin{abstract}
In this research, tin ferrite $\left(\mathrm{SnFe}_{2} \mathrm{O}_{4}\right)$ NPs were synthesized via hydrothermal route using ferric chloride and tin chloride as precursors and were then characterized in terms of morphology and structure using Fourier-transform infrared spectroscopy (FTIR), Ultraviolet-visible spectroscopy (UV-Vis), X-ray power diffraction (XRD), Scanning electron microscopy (SEM), Transmission electron microscopy (TEM), and Brunauer-Emmett-Teller (BET) method. The obtained UV-Vis spectra was used to measure band gap energy of as-prepared $\mathrm{SnFe}_{2} \mathrm{O}_{4} \mathrm{NPs}$. XRD confirmed the spinel structure of NPs, while SEM and TEM analyses disclosed the size of NPs in the range of 15-50 nm and revealed the spherical shape of NPs. Moreover, energy dispersive X-ray spectroscopy (EDS) and BET analysis was carried out to estimate elemental composition and specific surface area, respectively. In vitro cytotoxicity of the synthesized NPs were studied on normal (HUVEC, HEK293) and cancerous (A549) human cell lines. HUVEC cells were resistant to $\mathrm{SnFe}_{2} \mathrm{O}_{4} \mathrm{NPs}$; while a significant decrease in the viability of HEK293 cells was observed when treated with higher concentrations of $\mathrm{SnFe}_{2} \mathrm{O}_{4} \mathrm{NPs}_{\text {. }}$ Furthermore, $\mathrm{SnFe}_{2} \mathrm{O}_{4}$ NPs induced dramatic cytotoxicity against A549 cells. For in vivo study, rats received $\mathrm{SnFe}_{2} \mathrm{O}_{4} \mathrm{NPs}$ at dosages of $0,0.1,1$, and $10 \mathrm{mg} / \mathrm{kg}$. The $10 \mathrm{mg} / \mathrm{kg}$ dose increased serum blood urea nitrogen and creatinine compared to the controls $(\mathrm{P}<0.05)$. The pathology showed necrosis in the liver, heart, and lungs, and the greatest damages were related to the kidneys. Overall, the in vivo and in vitro experiments showed that $\mathrm{SnFe}_{2} \mathrm{O}_{4}$ NPs at high doses had toxic effects on lung, liver and kidney cells without inducing toxicity to HUVECs. Further studies are warranted to fully elucidate the side effects of $\mathrm{SnFe}_{2} \mathrm{O}_{4} \mathrm{NPs}$ for their application in theranostics.
\end{abstract}

Keywords: nanoparticles; tin ferrite; nanoceramics; cytotoxicity; in vivo toxicity; growth inhibition; nanomedicine

\section{Introduction}

Today, nanomedicine deals with the application of accurately engineered materials to emerge new modalities in theranostics [1]. These nanomaterials are ultra-small and highly reactive, making useful tools for overcoming limitations observed in conventional theranostic agents [2]. Cancer cells have high hydrogen peroxide levels that can catalyze the Fenton reaction, resulting in anticancer reactive oxygen species (ROS) [3]. Ferrite nanoparticles are of huge interest due to their comprehensive range of usages in many fields such as high-technology devices, catalysis, medicine, removal of organic contaminants, and pharmaceutical science [4,5]. Spinel ferrites are the foremost class of such materials because 
of their intensified catalytic, optical, electronic, magnetic, and electrical characteristics. Spinel ferrites possess generalized formula of $\mathrm{M}^{\mathrm{II}} \mathrm{Fe}_{2} \mathrm{O}_{4}$ (where $\mathrm{M}^{\mathrm{II}}=\mathrm{Fe}, \mathrm{Mn}$, Ni, etc.), and the unit cell with 32 oxygen atoms possess face-centred compact packing. By varying the nature of the bivalent ion $\mathrm{M}^{2+}$, one can get ferrites with different magnetic and physical properties [6,7].

It has been established that $\mathrm{SnFe}_{2} \mathrm{O}_{4}$ nanocrystals facilitate the Fenton reaction within cancer cells and induce apoptotic cell death. However, they seem not to affect cells with normal physiology. Thus, $\mathrm{SnFe}_{2} \mathrm{O}_{4}$ nanocrystals could serve as selective cancer eradicators [8]. Metal oxide-based nanoparticles have been making notable endowments to promote novel delivery systems in chemotherapy and radiation therapy. The application of inorganic nanoparticles for cancer treatment and drug delivery is growing day by day because of the numerous experiments conducted to increase their bioavailability and effectiveness [9]. Metal oxide-based nanoparticles are a group of inorganic materials that have attracted considerable attention in nanomedicine and biotechnology [10]. To the best of our knowledge, there is no data in the literature regarding the short-term toxicity of $\mathrm{SnFe}_{2} \mathrm{O}_{4}$ nanoparticles (NPs) in laboratory animals. Few works have been conducted to explore the consequences of $\mathrm{SnFe}_{2} \mathrm{O}_{4} \mathrm{NPs}$ on normal and cancer cell lines in the cell culture medium. It was noted that $\mathrm{SnFe}_{2} \mathrm{O}_{4}$ NPs were well tolerated by normal cells, exhibiting normal physiological levels of catalase. In contrast, $\mathrm{SnFe}_{2} \mathrm{O}_{4} \mathrm{NPs}$ showed effective in vitro cytotoxicity against cancer cells by activating heterogeneous Fenton reactions-an efficacious and auspicious selective cancer cell treatment process [8].

If not killing normal cells, magnetic NPs could serve as a promising multifunctional theranostic nano-platform in imaging guided cancer therapy. Despite the diverse applications of $\mathrm{SnFe}_{2} \mathrm{O}_{4}$ NPs in industry and medical engineering, there is a paucity of data about the in vivo and in vitro toxicity and relevant fundamental mechanisms of these structures. To the best of our knowledge, the biochemical effects of $\mathrm{SnFe}_{2} \mathrm{O}_{4} \mathrm{NPs}_{\text {have not }}$ been investigated in laboratory rodents. Furthermore, there is no published data regarding the histopathological effects of $\mathrm{SnFe}_{2} \mathrm{O}_{4}$ NPs on organs such as the liver, kidney, lung, testis, and brain. The current work aims at bridging this gap and is directed to investigate the potential in vitro and in vivo toxicity of $\mathrm{SnFe}_{2} \mathrm{O}_{4} \mathrm{NPs}$ on different cells/organs.

\section{Materials and Methods}

\subsection{Materials}

Ferric chloride hexahydrate $\left(\mathrm{FeCl}_{3} \cdot 6 \mathrm{H}_{2} \mathrm{O}\right)$, stannous chloride dihydrate $\left(\mathrm{SnCl}_{2} \cdot 2 \mathrm{H}_{2} \mathrm{O}\right)$, acetonitrile, and sodium hydroxide $(\mathrm{NaOH})$ were purchased from Sigma Aldrich (SigmaAldrich, Darmstadt, Germany) and used as received.

\subsection{Preparation of $\mathrm{SnFe}_{2} \mathrm{O}_{4} \mathrm{NPS}$}

A facile and cost-effective hydrothermal approach was followed to synthesize highquality nano-sized particles [11]. Following this typical procedure, $\mathrm{SnFe}_{2} \mathrm{O}_{4} \mathrm{NPs}_{\text {sere }}$ synthesized with specific ratios of precursors, i.e., tin chloride, ferric chloride and sodium hydroxide. In the first step, ferric chloride $(3.03 \mathrm{~g})$ and tin chloride $(0.6 \mathrm{~g})$ were added in stoichiometric amounts and subjected to stirring for $30 \mathrm{~min}$; then, $10 \mathrm{~mL}$ of $1 \mathrm{M}$ sodium hydroxide was added as precipitating agent and the batch was further stirred vigorously for $90 \mathrm{~min}$ at $80{ }^{\circ} \mathrm{C}$. The resultant reaction mixture was then transferred to stainless steel autoclave for $24 \mathrm{~h}$ at $150{ }^{\circ} \mathrm{C}$. The as-prepared particles were collected, filtered, and washed with ethanol. The filtered product was placed in an oven at $100{ }^{\circ} \mathrm{C}$ and, after this, calcination of the prepared $\mathrm{SnFe}_{2} \mathrm{O}_{4} \mathrm{NPs}$ was carried out at $300^{\circ} \mathrm{C}$ in a muffle furnace for $4 \mathrm{~h}$ to remove any kind of impurity, if present.

\subsection{Characterization}

Diverse analytical characterization approaches were extensively utilized to explore the morphological and structural attributes of resultant samples. Ultraviolet-visible spectrum was measured through UV-vis spectrophotometer (Shimazdu Corporation, Kyoto, Japan) 
with resolution of $0.1 \mathrm{~nm}$ and accuracy of $0.3 \mathrm{~nm}$. The functional group characterization was accomplished while taking FTIR spectra from spectrometer within the range between 500 and $4000 \mathrm{~cm}^{-1}$. X-ray diffractometer (Miniflex 600, Rigaku Corporation, Tokyo, Japan) was utilized to investigate XRD patterns that were recorded by using $\mathrm{CuK} \alpha$ radiation $(1.54 \AA)$ from $25^{\circ}$ to $70^{\circ}$ with angle of deviation of $0.01^{\circ}$ and accuracy of $0.005^{\circ}$. The morphology and composition of samples were investigated by SEM and EDS, respectively (SEM equipped with EDS, JSM-6390LV, JEOL, Tokyo, Japan); TEM analysis was performed as well (Philips EM-400, Amsterdam, Netherlands; operating voltage $120 \mathrm{kV}$ ). The adsorption-desorption of $\mathrm{N}_{2}$ at $-196{ }^{\circ} \mathrm{C}$ was used for textural characterization. BET method was performed for evaluating the specific surface area of $\mathrm{SnFe}_{2} \mathrm{O}_{4}$ NPs; pore volume and mean pore size were determined by using the Barrett-Joyner-Halenda (BJH) method.

\subsection{Cells and Culture Condition}

A549 human lung cancer cells were selected as an in vitro solid tumor model. Human embryonic kidney cells (HEK293) and human umbilical vein endothelial cells (HUVECs) were chosen as widely studied non-cancerous cell lines for cytotoxicity assessment.

HEK293 and A549 cells were obtained from cell repository of Royan Institute (Tehran, Iran). HUVEC cells were a kind gift from Dr. Roghayeh Sheervalilou. Both HEK293 and HUVEC cell lines were maintained in Dulbecco's Modified Eagle's medium (Gibco, Rockville, MD, USA), while the A549 cells were cultivated in RPMI1640 medium (Gibco, Rockville, MD, USA). Culture mediums were augmented with $10 \%$ heat-inactivated fetal bovine serum (FBS, Biochrome, Berlin, Germany), $250 \mu \mathrm{g} / \mathrm{mL}$ amphotericin B (SigmaAldrich, Steinheim am Albuch, Germany), $50 \mathrm{U} / \mathrm{mL}$ penicillin (Sigma-Aldrich, Steinheim am Albuch, Germany), and $50 \mu \mathrm{g} / \mathrm{mL}$ streptomycin (Sigma-Aldrich, Steinheim am Albuch, Germany) and kept at standard cell culture conditions [12]. The culture media were changed every 2 or 3 days. At $80 \%$ confluency, cells attached to the culture flask were trypsinized and passed to new culture flasks (Jet biofil, Sorfa, Germany) at a cell density of 5000 cells $/ \mathrm{cm}^{2}$.

\subsection{In Vitro Cytotoxicity Evaluation}

The growth inhibitory effect of $\mathrm{SnFe}_{2} \mathrm{O}_{4}$ NPs was assessed using a tetrazolium (MTT)based colorimetric assay [13]. Cells $\left(5 \times 10^{3}\right.$ cells/well) were seeded in a 96-well plate (Sorfa Life Science Research Co., Ltd., Zhejiang, China) and incubated overnight to allow cell adhesion. $\mathrm{SnFe}_{2} \mathrm{O}_{4} \mathrm{NPs}(50 \mathrm{mg}$ ) were dispersed in distilled water to prepare a $169.8 \mathrm{mM}$ stock solution. Cells were then treated with increasing concentrations (50-1600 $\mu \mathrm{M})$ of $\mathrm{SnFe}_{2} \mathrm{O}_{4} \mathrm{NPs}$ prepared in a culture medium. After 24 to $72 \mathrm{~h}$ incubation, MTT dye (SigmaAldrich, St. Louis, MO) at a dosage of $5 \mathrm{mg} / \mathrm{mL}$ was poured into a particular well and nurtured for $3 \mathrm{~h}$ at $37^{\circ} \mathrm{C}$. Optical density was assessed by eluting the dye with dimethyl sulfoxide (Sigma, St. Louis, MO, USA). The absorbance was measured at $570 \mathrm{~nm}$ using a SpectraMax Gemini microtiter plate reader (Molecular Devices, Sunnyvale, CA, USA). Cell growth (expressed as a percentage) was ascertained by dividing the absorbance measured for treated cells by the absorbance measured for non-treated cells. The evaluation was repeated threefold.

\subsection{Animal Treatments and Experimental Design}

In the current experimental study, thirty-two male adult white rats (Wistar breed) with a mean weight of $234 \mathrm{~g}$ were utilized. The animals were acquired from the animal breeding colonies present at the centre of laboratory animal research of Zabol University. Rats were housed in groups of three animals in each polycarbonate cage. The room where the animals were held had a standard temperature $\left(25^{\circ} \mathrm{C}\right)$ and light program. Rats had free access to normal laboratory rodent pellets (manufactured by Javaneh-Khorasan company, Mashhad, Iran). In order to get the animals ready for the experiments, rats were subjected to an adaptation period that was lasted for two weeks. The animal treatments were carried out according to the international guidelines of Care and Use of Laboratory Animals (from 
NIH Publication No. 85-23) and Zabol University's institutional ethical research committee instructions. Rats were arbitrarily and equally distributed into four classes as follows: the healthy control rats received $0.5 \mathrm{~mL}$ physiological saline intraperitoneally for three weeks, the second group received daily intraperitoneal $0.1 \mathrm{mg} / \mathrm{kg}$ dose of $\mathrm{SnFe}_{2} \mathrm{O}_{4} \mathrm{NPs}$, the third group was treated by daily intraperitoneal injection of $1 \mathrm{mg} / \mathrm{kg} \mathrm{SnFe}_{2} \mathrm{O}_{4} \mathrm{NPs}$, and the fourth group received the highest dose $(10 \mathrm{mg} / \mathrm{kg})$ of $\mathrm{SnFe}_{2} \mathrm{O}_{4} \mathrm{NPs}$ intraperitoneally for twenty-one days. Finally, after three weeks, blood samples were collected by retro-orbital sinus puncture and immediately centrifuged ( $1500 \mathrm{rpm}$ for $10 \mathrm{~min}$ ). After being centrifuged, the obtained serum samples were stored at $-20^{\circ} \mathrm{C}$ till the start of the biochemical analysis.

\subsection{Serum Biochemical Parameters}

The quantities of blood urea nitrogen (BUN), aspartate aminotransferase (AST), alanine aminotransferase (ALT), and creatinine present in serum samples were determined using the Pars Azmoon Company colorimetric kits. The Selectra Pro M autoanalyzer (Vital Scientific, Spankeren, Netherlands) was used for biochemical analysis. Serum malondialdehyde content was calculated by employing the procedure reported by Ohkawa et al. [14]. After three weeks of intraperitoneal injections, rats were euthanized in a human fashion by a high dose of pentobarbital anesthesia. Liver, kidney, lung, and heart tissues were sliced in $0.5 \mathrm{~cm} \times 0.5 \mathrm{~cm} \times 0.5 \mathrm{~cm}$ cubes and maintained in neutral buffered formalin for two days. After $48 \mathrm{~h}$, the formalin was replaced by new formalin, and the specimens were sent to the histopathological laboratory for paraffin treatment and paraffin block making.

Paraffin blocks were cut into 4-6 $\mu \mathrm{m}$ thick segments. Successive sections were pigmented with hematoxylin-eosin and examined by a light microscope (Olympus, Tokyo, Japan) for detecting any histopathological changes.

\subsection{Statistical analysis}

The statistical analysis of biochemical data was performed by SPSS 20 (IBM Statistics, New York, NY, USA). The one-way analysis of variance (ANOVA) and the Tukey post-hoc test was employed to detect the variation among the control group and experimental groups at $\mathrm{P}<0.05$.

\section{Results}

\subsection{Characterization of $\mathrm{SnFe}_{2} \mathrm{O}_{4} \mathrm{NPS}$}

The FTIR spectrum of as-synthesized $\mathrm{SnFe}_{2} \mathrm{O}_{4}$ NPs is shown in Figure 1. The characteristic absorption bands in the range between 1600 and $1644 \mathrm{~cm}^{-1}$ were attributed to the statistical bending vibration of $\mathrm{O}-\mathrm{H}$ bond of hydroxyl group $\left(\mathrm{v}_{3}\right)$. The intense peak at $614.25 \mathrm{~cm}^{-1}$ corresponds to the presence of $\mathrm{Sn}-\mathrm{O}$ bond of tin-ferrite NPs $\left(\mathrm{v}_{1}\right)$. The broad signal in the range of $3172.91-3366.55 \mathrm{~cm}^{-1}$ indicates the stretching of $\mathrm{O}-\mathrm{H}$ bond $\left(\mathrm{v}_{4}\right)$. Moreover, the adsorption band at $846.99 \mathrm{~cm}^{-1}$ corresponds to the vibrational modes of tin and iron in tetrahedral and octahedral sites $\left(\mathrm{v}_{2}\right)$.

Figure 2 represents the UV-Vis spectrum of $\mathrm{SnFe}_{2} \mathrm{O}_{4} \mathrm{NPs}$, which was used to calculate the value of band gap energy. The energy required to excite electrons from valence to conductance band, for this sample, is found to be $5.23 \mathrm{eV}$. This numerical value is estimated from Tauc plot. Furthermore, the high values predict the decrease in the size of nanoparticle. 


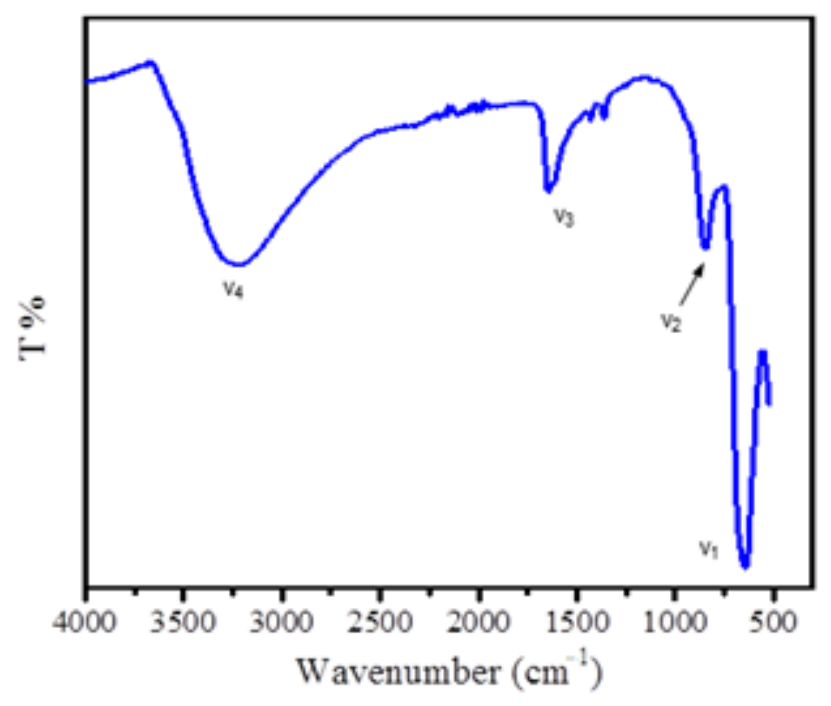

Figure 1. FTIR spectrum of fabricated $\mathrm{SnFe}_{2} \mathrm{O}_{4}$ nanoparticles (NPs).

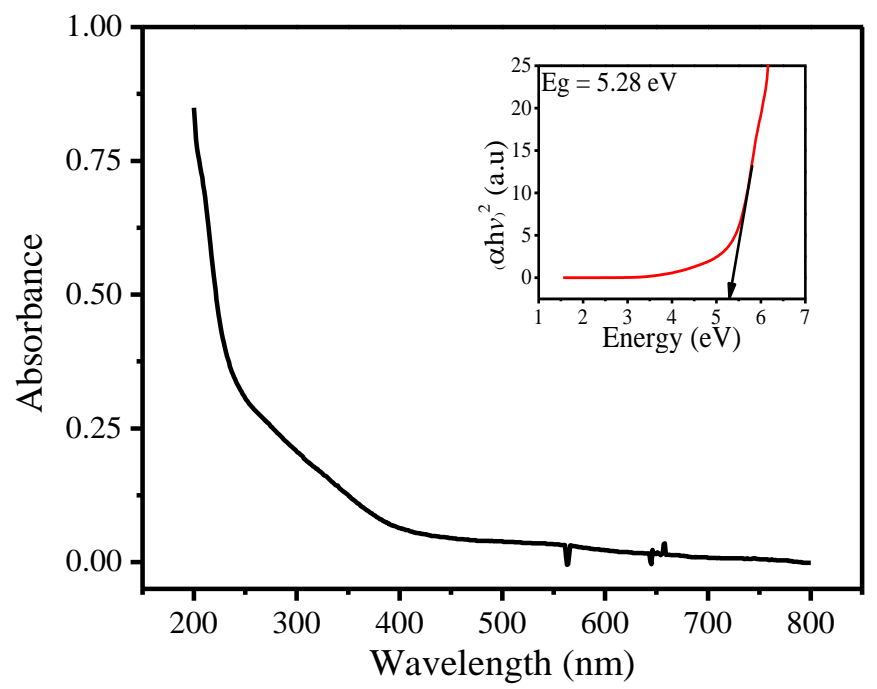

Figure 2. UV-visible spectrum along with Tauc plot of fabricated $\mathrm{SnFe}_{2} \mathrm{O}_{4} \mathrm{NPs}$.

XRD pattern (Figure 3) of fabricated $\mathrm{SnFe}_{2} \mathrm{O}_{4}$ NPs represents a series of narrow and broad diffraction signals characteristic for pure and good-quality nanoparticles. In accordance to JCPDS database, the single-phase spinel-related structure was identified (code 22-1086) [11]. The mean size of crystallites was determined by using Scherrer equation and was found in the range of 15 to $50 \mathrm{~nm}$. The $\mathrm{SnFe}_{2} \mathrm{O}_{4}$ NPs exhibited the major diffraction signals attributed to (111), (220), (311), (222), (400), (422), (511), (440), (620), and (533) reflections, corresponding to the crystallographic planes of highly defined lattice of $\mathrm{SnFe}_{2} \mathrm{O}_{4} \mathrm{NPs}$. 


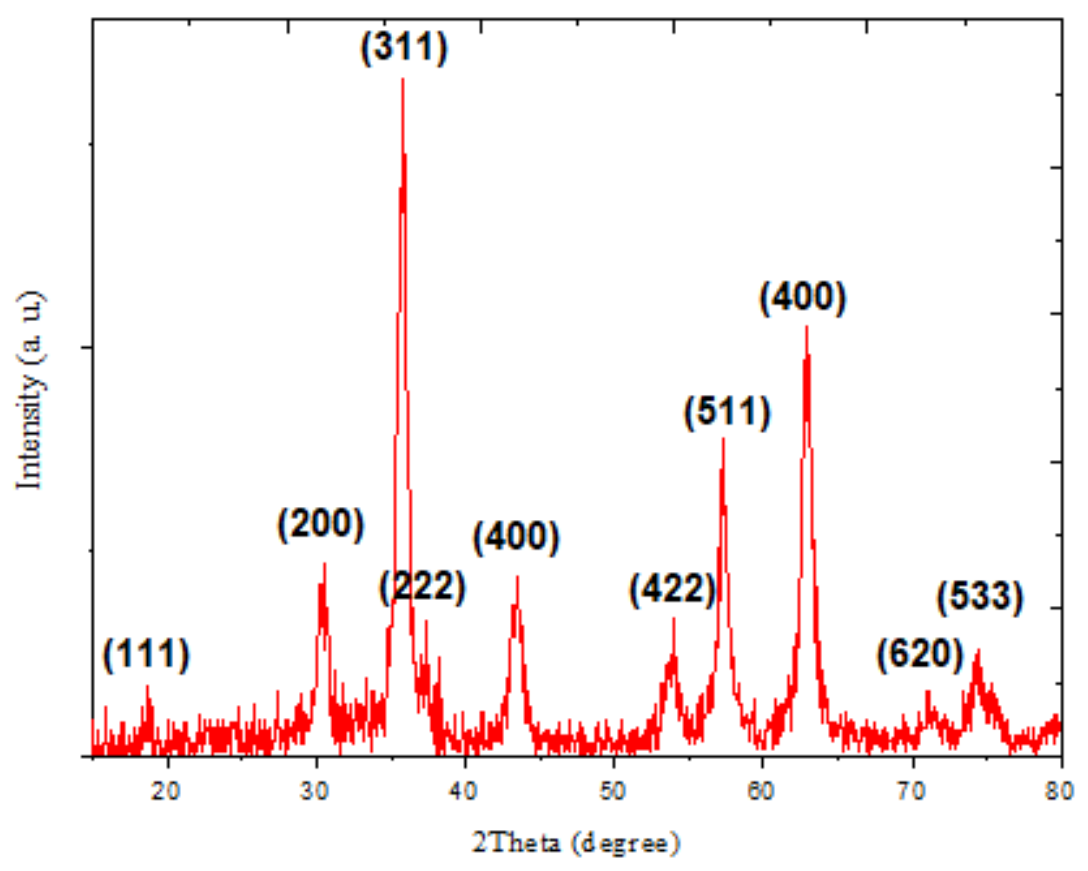

Figure 3. XRD pattern of $\mathrm{SnFe}_{2} \mathrm{O}_{4}$ NPs prepared by hydrothermal method.

The SEM micrograph for $\mathrm{SnFe}_{2} \mathrm{O}_{4} \mathrm{NPs}$ that have been produced by hydrothermal treatment is shown in Figure 4A. The particles prepared by this method are mono-dispersed and highly pure because of preferential nucleation and growth in the fabrication process, $\mathrm{SnFe}_{2} \mathrm{O}_{4}$ NPs with distinctive spherical morphology have been created. Moreover, the agglomeration/aggregation of NPs can also be seen in SEM image.

TEM micrographs of as-prepared $\mathrm{SnFe}_{2} \mathrm{O}_{4} \mathrm{NPs}$ are reported in Figure 4B,C. The TEM micrographs reveal that $\mathrm{SnFe}_{2} \mathrm{O}_{4}$ NPs fabricated via hydrothermal method exhibit quite uniform particle distribution and morphology with round shape. TEM analysis disclosed the size of NPs in the range of 15-50 nm.

EDS pattern shown in Figure 4D ascertained the presence of iron, oxygen, and tin in the NPs, in accordance with theoretical expectations; this is also consistent with XRD results confirming the tin-ferrite phase $\left(\mathrm{SnFe}_{2} \mathrm{O}_{4}\right)$.

In order to estimate the surface area, pore volume, and pore size distribution of $\mathrm{SnFe}_{2} \mathrm{O}_{4}$ NPs, BET analysis was performed (Figure 5). This material demonstrates the adsorption-desorption isotherm of type-IV with the value of hysteresis loop in the range of 0.52-0.96 indicating the existence of numerous pores in the described structure of $\mathrm{SnFe}_{2} \mathrm{O}_{4}$ NPs. The specific surface area, pore volume and mean pore diameter of as-prepared $\mathrm{SnFe}_{2} \mathrm{O}_{4} \mathrm{NPs}$ are found to be $42.92 \mathrm{~m}^{2} / \mathrm{g}, 0.212 \mathrm{~cm}^{3} / \mathrm{g}$, and $19.76 \mathrm{~nm}$, respectively. 

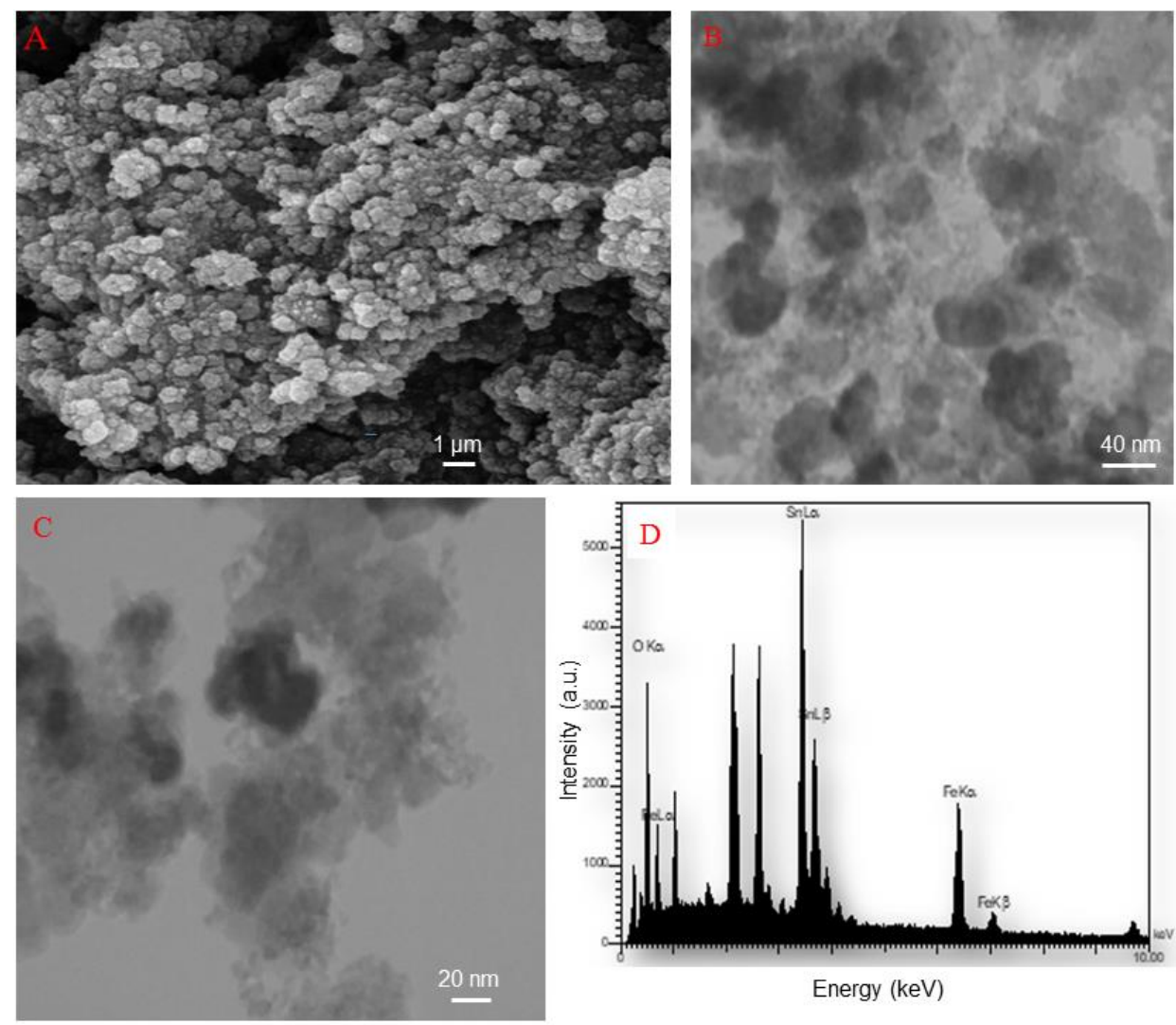

Figure 4. SEM image (A), TEM image (B,C), and EDS spectra (D) of synthesized $\mathrm{SnFe}_{2} \mathrm{O}_{4} \mathrm{NPs}_{\text {. }}$

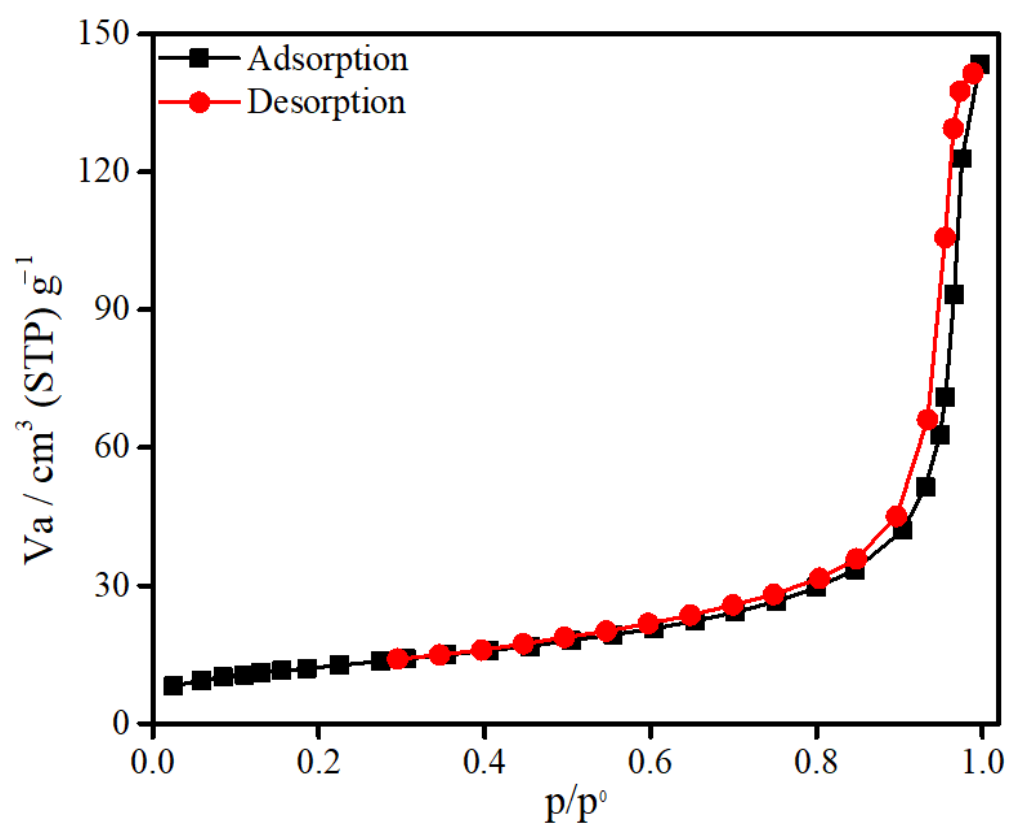

Figure 5. Nitrogen adsorption-desorption isotherm plot of synthesized $\mathrm{SnFe}_{2} \mathrm{O}_{4} \mathrm{NPs}_{\text {. }}$

\subsection{Determination of Cell Sensitivity to $\mathrm{SnFe}_{2} \mathrm{O}_{4} \mathrm{NPS}$}

No significant decrease in the viability of HUVECs was noticed after 24 to $72 \mathrm{~h}$ exposure to $\mathrm{SnFe}_{2} \mathrm{O}_{4} \mathrm{NPs}$ ( $\mathrm{P}>0.05$ compared with adjusted untreated cells) (Figure 6). On the contrary, after being exposed for 24, 48, and $72 \mathrm{~h}$ to high concentrations of $\mathrm{SnFe}_{2} \mathrm{O}_{4}$ NPs, HEK293 cells exhibited a marked decrease in viability in a concentration- and time- 
dependent fashion $(\mathrm{P}<0.05$ in contrast with adjusted unprocessed cells) (Figure 7). The half-maximal inhibitory concentrations (IC50) estimated using GraphPad Prism software version 7.0 for 24, 48, and $72 \mathrm{~h}$ treatment of HEK293 cells with $\mathrm{SnFe}_{2} \mathrm{O}_{4} \mathrm{NPs}$ were 3716, 2195, and $1116 \mu \mathrm{M}$, respectively. As regards A549 cells, significant concentration- and time-dependent cell toxicity was observed after exposure to different concentrations of $\mathrm{SnFe}_{2} \mathrm{O}_{4} \mathrm{NPs}$, reducing the cell viability by 10 to $99.5 \%$ at a given time $(\mathrm{P}<0.05$ in contrast with adjusted unprocessed cells) (Figure 8). The calculated IC50 values for the treatment of A549 cells with $\mathrm{SnFe}_{2} \mathrm{O}_{4}$ NPs were $651.1 \mu \mathrm{M}$ (after $24 \mathrm{~h}$ ), $381.3 \mu \mathrm{M}$ (after $48 \mathrm{~h}$ ), and $141.2 \mu \mathrm{M}$ (after $72 \mathrm{~h}$ ).

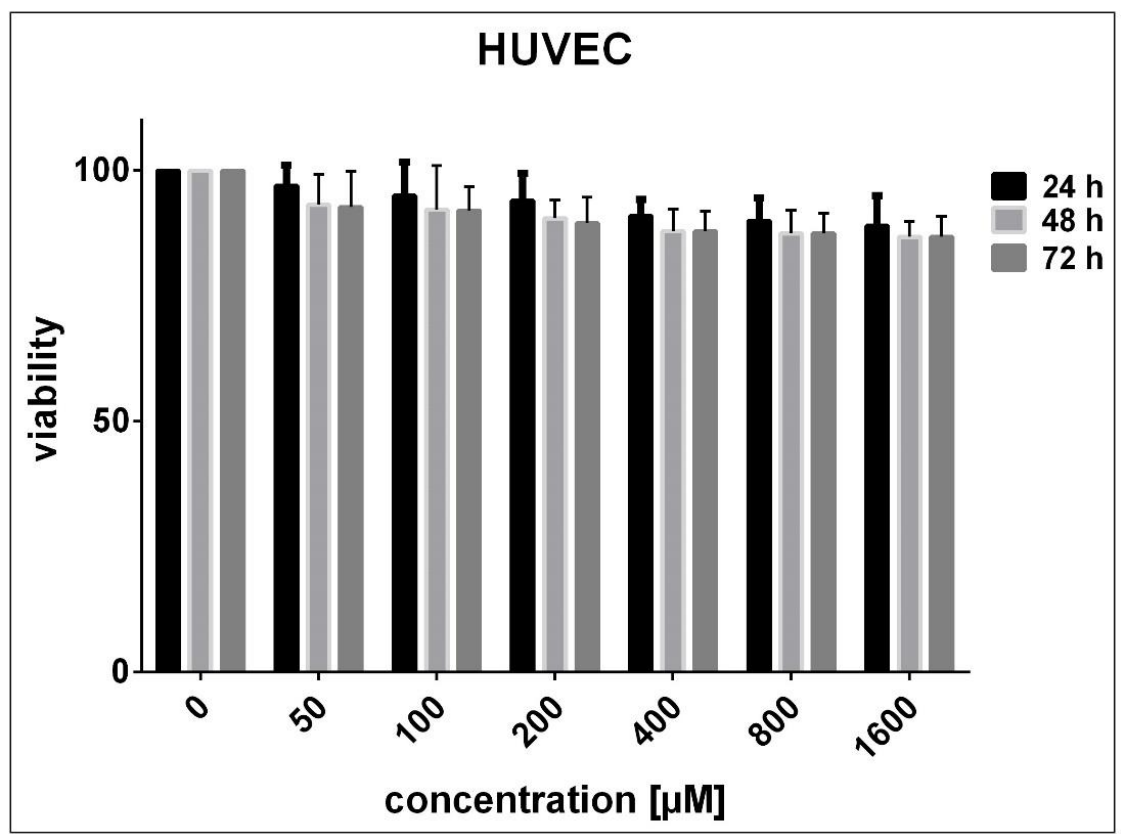

Figure 6. Cytotoxic effects $\mathrm{SnFe}_{2} \mathrm{O}_{4} \mathrm{NPs}$ on HUVECs using MTT analysis following 24, 48, and $72 \mathrm{~h}$ exposure. No significant reduction in cell viability was observed ( $\mathrm{P}>0.05$ compared with untreated cells).

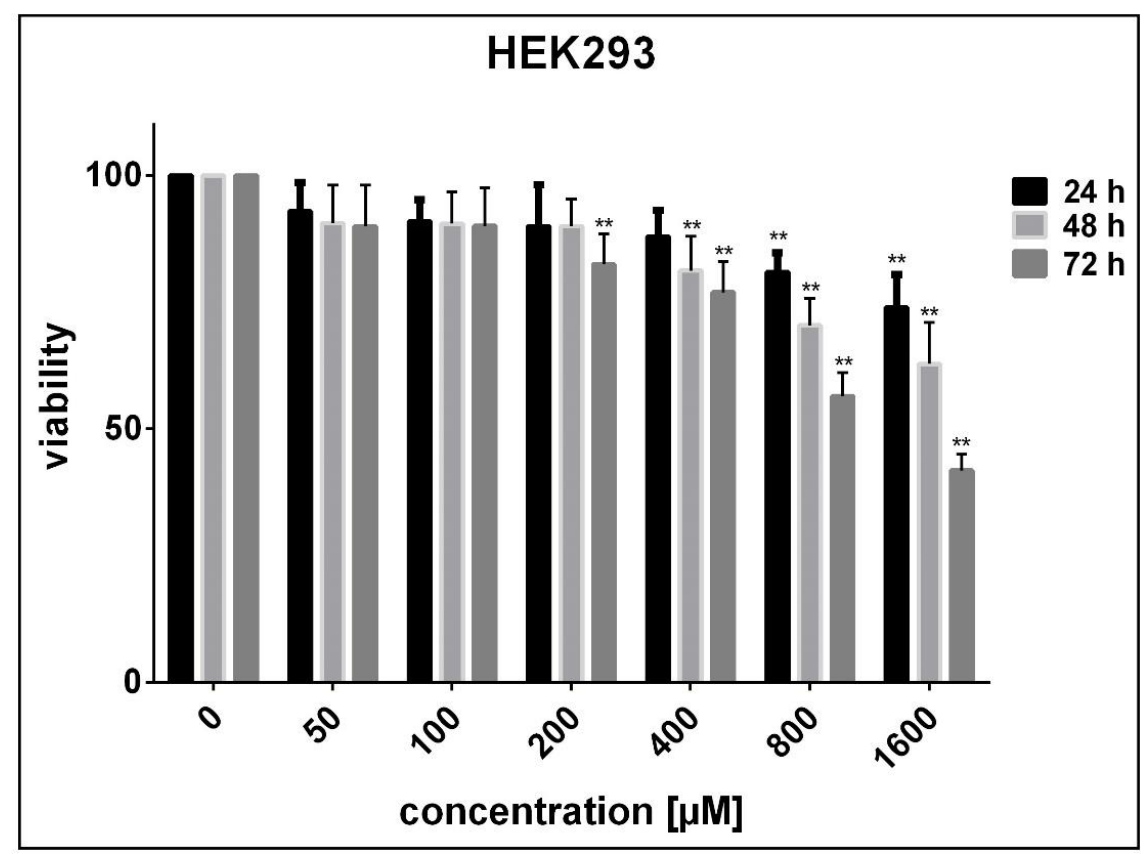

Figure 7. Cytotoxic effects $\mathrm{SnFe}_{2} \mathrm{O}_{4}$ NPs on HEK293 cells by using MTT analysis following 24, 48, and $72 \mathrm{~h}$ exposure. $(* * \mathrm{P}<0.05$ compared with untreated cells). 


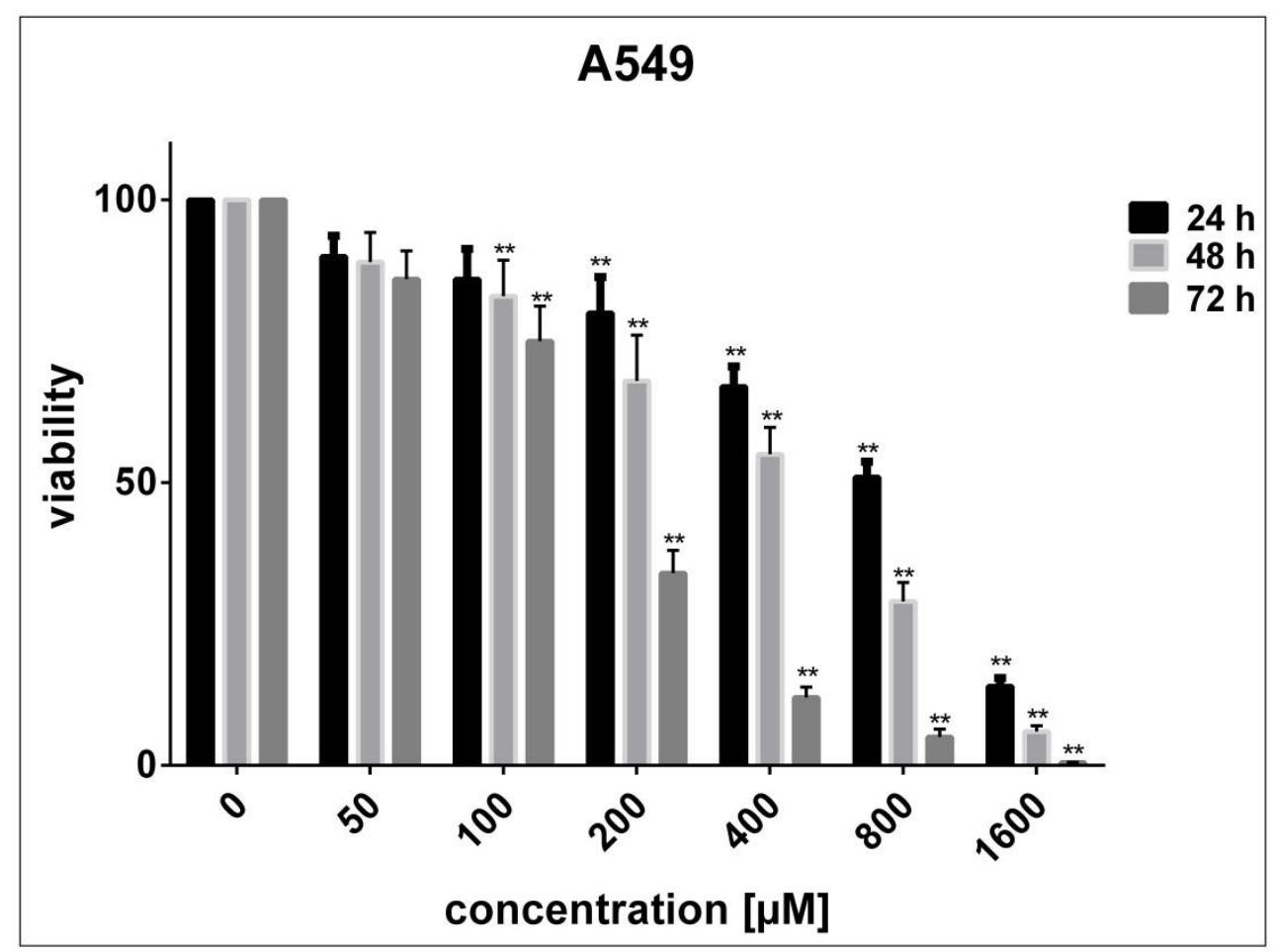

Figure 8. Cytotoxic consequences $\mathrm{SnFe}_{2} \mathrm{O}_{4}$ NPs on A549 lung cancer cells by using MTT analysis following 24, 48 , and $72 \mathrm{~h}$ exposure. (** $\mathrm{P}<0.05$ compared with untreated cells).

\subsection{Biochemical Results}

Intraperitoneal injections of $\mathrm{SnFe}_{2} \mathrm{O}_{4}$ at a dose of $0.1 \mathrm{mg} / \mathrm{kg}$ had no significant effect on serum aspartate aminotransferase, serum alanine aminotransferase, serum blood urea nitrogen, and serum creatinine levels $(\mathrm{P}<0.05)$ (Table 1$)$. The intraperitoneal treatment of rats with $\mathrm{SnFe} 2 \mathrm{O} 4$ at $4 \mathrm{mg} / \mathrm{kg}$ body weight caused no biochemical changes in serum liver enzymes and serum BUN, and creatinine levels $(\mathrm{P}<0.05)$ (Table 1$)$. The high-dose administration of $\mathrm{SnFe}_{2} \mathrm{O}_{4}$ caused no significant changes in serum alanine aminotransferase and serum aspartate aminotransferase; however, serum levels of blood urea nitrogen and creatinine were significantly higher compared to the control rats $(P<0.05)$. Serum lipid peroxidation was also increased in the high-dose treated rats $(\mathrm{P}<0.05)$.

Table 1. Serum biochemical parameters and lipid peroxidation in rats.

\begin{tabular}{|c|c|c|c|c|}
\hline \multirow{2}{*}{ Item } & \multicolumn{4}{|c|}{ Treatment } \\
\hline & Control & $\begin{array}{c}\mathrm{SnFe}_{2} \mathrm{O}_{4} \mathrm{Nanoparticles} \\
0.1 \mathrm{mg} / \mathrm{kg}\end{array}$ & $\begin{array}{c}\mathrm{SnFe}_{2} \mathrm{O}_{4} \\
\text { Nanoparticles } 1 \mathrm{mg} / \mathrm{kg}\end{array}$ & $\begin{array}{c}\mathrm{SnFe}_{2} \mathrm{O}_{4} \text { Nanoparticles } \\
10 \mathrm{mg} / \mathrm{kg}\end{array}$ \\
\hline MDA (nmol/mL) & $39 \pm 10.7$ & $37.5 \pm 8.6$ & $35 \pm 5.3$ & $52 \pm 8 *$ \\
\hline AST (U/L) & $65.6 \pm 12.4$ & $66.7 \pm 15.7$ & $77.6 \pm 12.9$ & $68.7 \pm 8.8$ \\
\hline ALT (U/L) & $31.5 \pm 8$ & $37.8 \pm 9.2$ & $31.2 \pm 8.6$ & $39.1 \pm 7.7$ \\
\hline $\mathrm{BUN}(\mathrm{mg} / \mathrm{dL})$ & $11.2 \pm 3.3$ & $12.1 \pm 2.6$ & $13.2 \pm 2.6$ & $16.3 \pm 4.1 *$ \\
\hline Creatinine (mg/dL) & $0.75 \pm 0.15$ & $0.81 \pm 0.24$ & $0.87 \pm 0.17$ & $1.1 \pm 0.38 *$ \\
\hline
\end{tabular}

* indicates statistical significant difference with control group $(\mathrm{P}<0.05)$. 
The histopathological investigations of different tissue samples, including lung, brain, liver, heart, kidney, and testis, are shown in Figures 9-14. In the current investigation, various tissues were stained with specific colors. As seen in Figure 9, the Alcian blue lung section of a control rat showed normal lung structure with normal type I and type II pneumocytes (Figure 9A). The groups subjected to the $0.1 \mathrm{mg} / \mathrm{kg}$ and $1 \mathrm{mg} / \mathrm{kg}$ doses of $\mathrm{SnFe}_{2} \mathrm{O}_{4}$ NPs also showed normal lung histopathology (Figure 9B,C). The lung section of a rat treated with $10 \mathrm{mg} / \mathrm{kg}$ dose of $\mathrm{SnFe}_{2} \mathrm{O}_{4}$ NPs showed hypertrophy of lung alveoli (Figure 9D). Alcian blue staining of the heart muscle of rats treated with $\mathrm{SnFe}_{2} \mathrm{O}_{4} \mathrm{NPs}$ at a dosage of 0.1 and $1 \mathrm{mg} / \mathrm{kg}$ showed normal morphology (Figure 10B,C). The heart section of a rat treated with $\mathrm{SnFe}_{2} \mathrm{O}_{4} \mathrm{NPs}$ at the dosage of $10 \mathrm{mg} / \mathrm{kg}$ showed some signs of cardiac hypertrophy (Figure 10D). The histopathological examination of liver tissues showed the normal histology of liver cells and hepatic cords in liver segments of rats treated with $\mathrm{SnFe}_{2} \mathrm{O}_{4} \mathrm{NPs}$ at a dose of $0.1 \mathrm{mg} / \mathrm{kg}$ (Figure 11B). Periodic acid-Schiff (PAS) staining of a liver section of rats treated with the $1 \mathrm{mg} / \mathrm{kg}$ dose of $\mathrm{SnFe}_{2} \mathrm{O}_{4} \mathrm{NPs}$ showed no prominent histopathological change (Figure 11C). Liver micrographs of the high-dose treated rats showed some signs of disarrangement of hepatic cords-an indicator of early liver cell damage-around the central veins (Figure 11D).

The histopathological changes in the kidneys of rats were more severe. While the glomerular structure of rats treated with the low dose of $\mathrm{SnFe}_{2} \mathrm{O}_{4} \mathrm{NPs}$ was normal (Figure 12B), the groups receiving the high doses of $\mathrm{SnFe}_{2} \mathrm{O}_{4}$ NPs showed preliminary signs of inflammation and renal failure; hyaline casts were also present (Figure 12D). Brain and testis tissues showed an overall normal histological appearance (Figure 13; Figure 14).

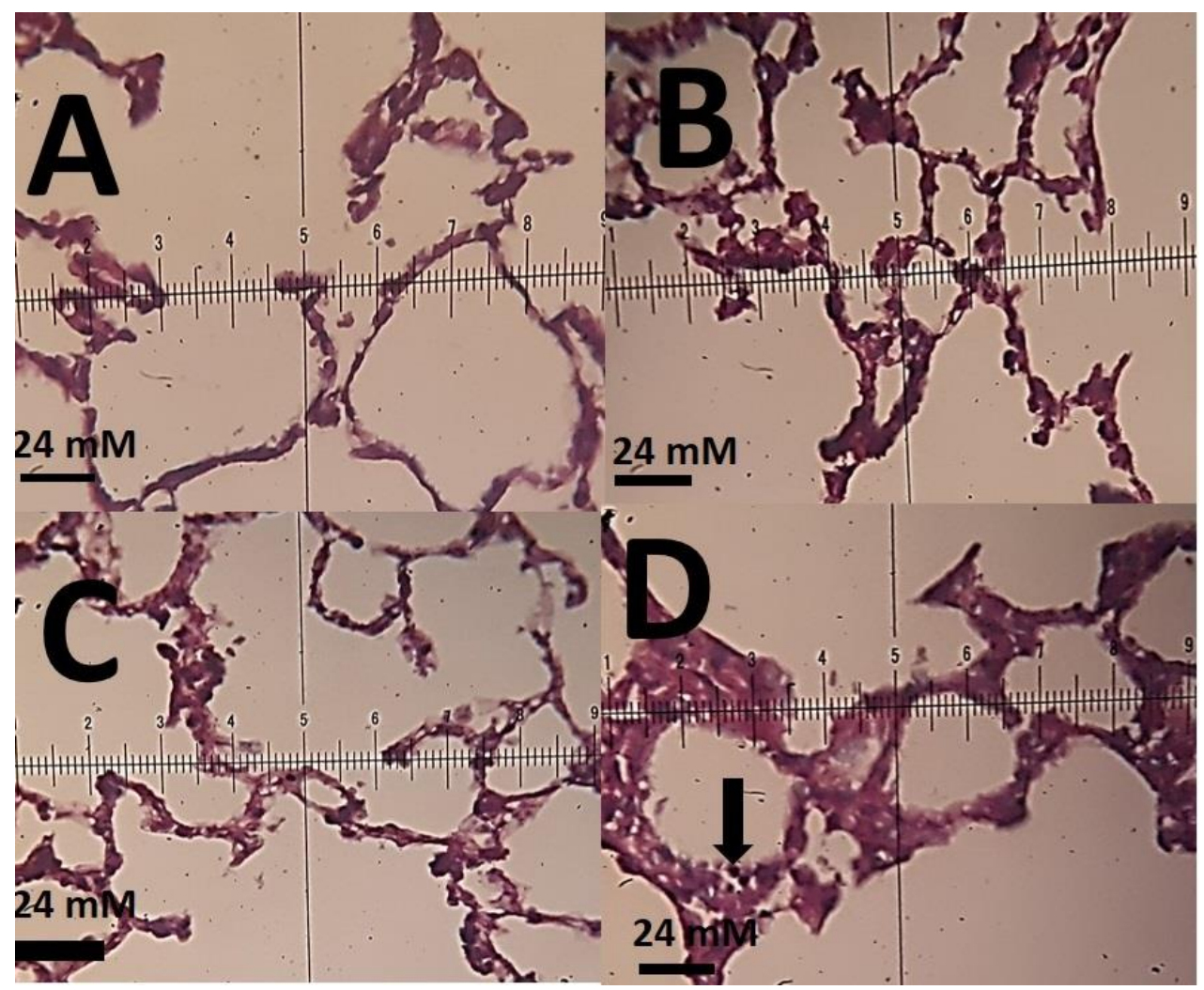

Figure 9. (A): Alcian blue micrograph of the lung of a control rat representing normal lung morphology with normal type I and type II pneumocytes $(\times 40)$; $(\mathbf{B})$ : lung section of a rat treated with $0.1 \mathrm{mg} / \mathrm{kg}$ $\mathrm{SnFe}_{2} \mathrm{O}_{4}$ NPs. Alcian blue staining $(\times 40)$; (C): lung section of a rat treated with $\mathrm{SnFe}_{2} \mathrm{O}_{4} \mathrm{NPs}$ at a dose of $1 \mathrm{mg} / \mathrm{kg}$. Alcian blue staining $(\times 40)$; (D): lung section of a rat treated with $\mathrm{SnFe}_{2} \mathrm{O}_{4} \mathrm{NPs}$ at a dosage of $10 \mathrm{mg} / \mathrm{kg}$ showing hypertrophy of lung alveoli (arrow), Alcian blue staining $(\times 40)$. 


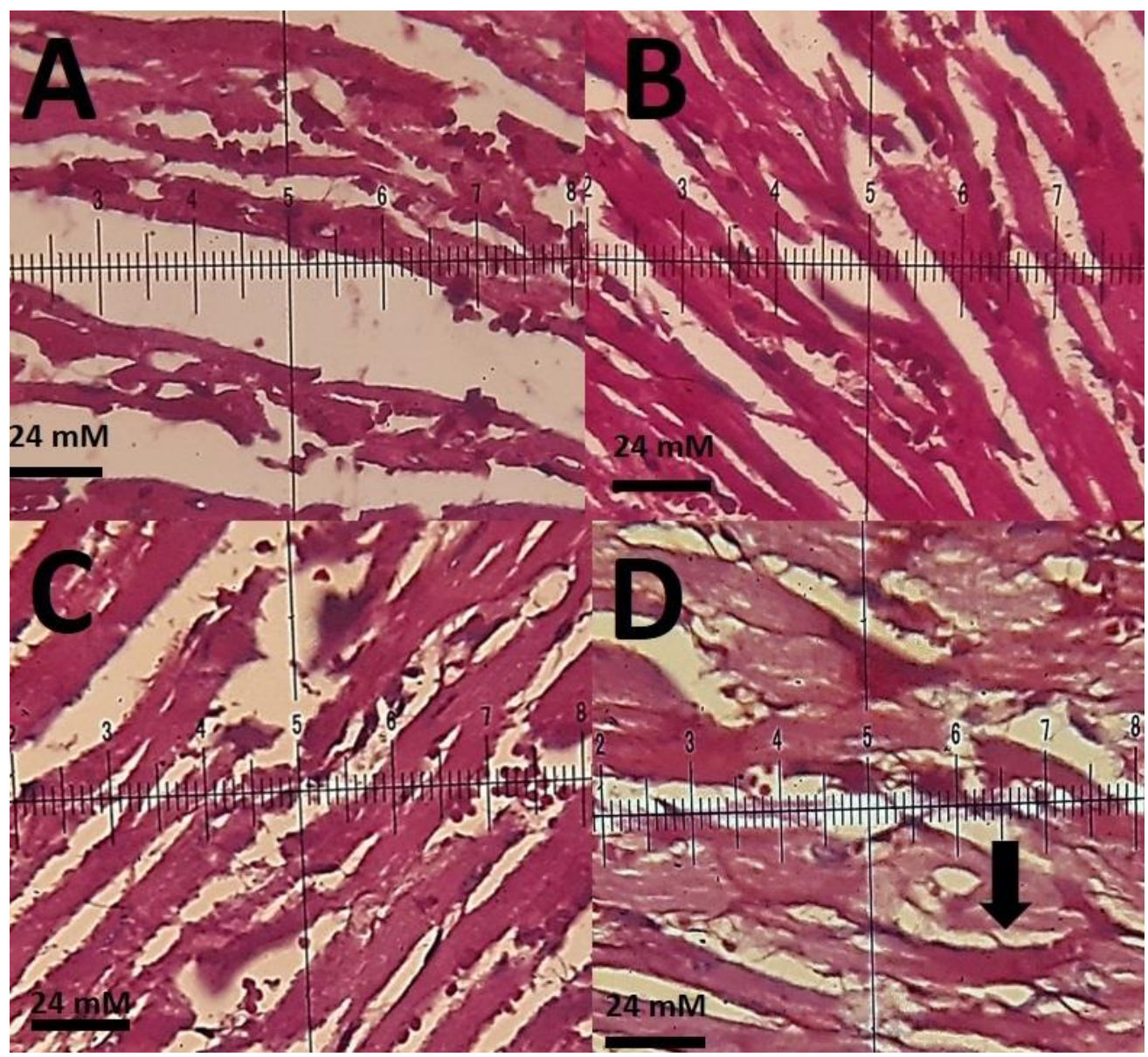

Figure 10. (A): Alcian blue staining of the heart muscle of a control rat representing normal histopathological aspects $(\times 40)$; (B): heart section of a rat treated with $\mathrm{SnFe}_{2} \mathrm{O}_{4} \mathrm{NPs}$ at a dosage of $0.1 \mathrm{mg} / \mathrm{kg}$. Alcian blue staining $(\times 40)$; (C): heart section of a rat treated with $\mathrm{SnFe}_{2} \mathrm{O}_{4} \mathrm{NPs}$ at a dose of $1 \mathrm{mg} / \mathrm{kg}$. Alcian blue staining $(\times 40)$; (D): heart section of a rat treated with $\mathrm{SnFe}_{2} \mathrm{O}_{4} \mathrm{NPs}$ at a dosage of $10 \mathrm{mg} / \mathrm{kg}$. Heart muscle hypertrophy is the main feature (arrow), Alcian blue staining $(\times 40)$. 


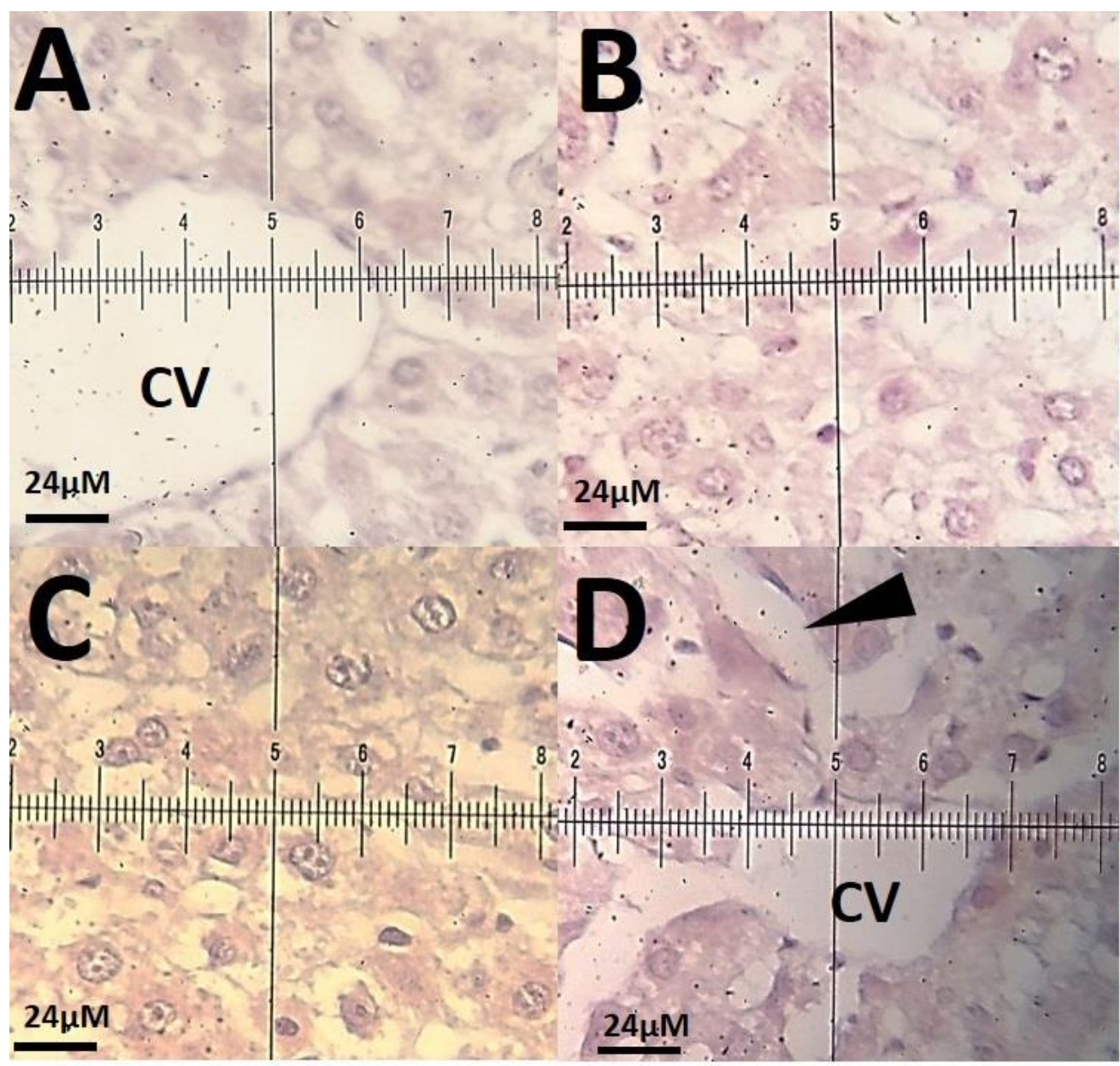

Figure 11. (A): Periodic acid-Schiff (PAS) staining of a liver section of a control rat showing the normal histology of hepatocytes and hepatic cords around the central vein $(\mathrm{CV})$. Bar $=24 \mu \mathrm{m}(\times 40)$; (B): liver segments of a rat processed with $\mathrm{SnFe}_{2} \mathrm{O}_{4} \mathrm{NPs}$ at a dose of $0.1 \mathrm{mg} / \mathrm{kg}$ with no prominent histopathological change. PAS-pigmentation $(\times 40)$; (C): liver section of a rat collected the $1 \mathrm{mg} / \mathrm{kg}$ dosage of $\mathrm{SnFe}_{2} \mathrm{O}_{4}$ NPs showing normal morphology of hepatocytes and hepatic cords. PAS-staining ( $\times 40)$; (D): liver segment of a rat treated with intraperitoneal injections of $10 \mathrm{mg} / \mathrm{kg} \mathrm{SnFe} 2 \mathrm{O}_{4} \mathrm{NPs}_{\text {, }}$ showing signs of disarrangement of hepatic cords (arrow point). PAS-staining $(\times 40)$. Scale bar indicates $40 \mu \mathrm{m}$. 


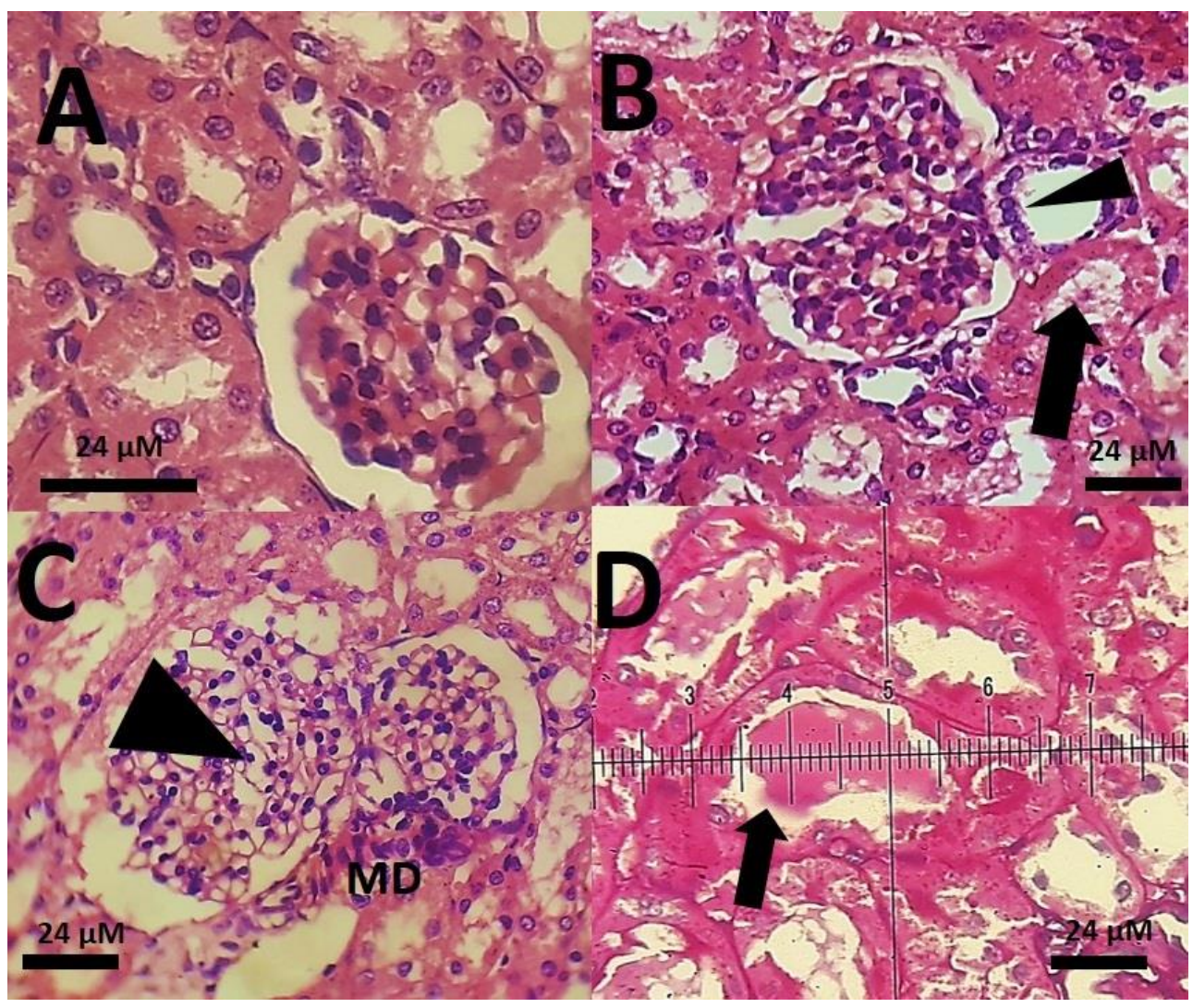

Figure 12. (A): Kidney portrayal of a rat stained with Alcian blue showing normal glomerular morphology and normal tubules; (B): renal image of a rat treated with $\mathrm{SnFe}_{2} \mathrm{O}_{4} \mathrm{NPs}$ at a dosage of $0.1 \mathrm{mg} / \mathrm{kg}$ with normal glumerole (arrow point) and the adjacent macula densa apparatus (MD); (C): rat kidney processed with $\mathrm{SnFe}_{2} \mathrm{O}_{4} \mathrm{NPs}$ at a dosage of $0.1 \mathrm{mg} / \mathrm{kg}$. Macula densa and glomerules have normal structure, but the preliminary signs of inflammation and renal failure are present (arrow). (D): A kidney Alcian blue-stained section of a rat treated with $\mathrm{SnFe}_{2} \mathrm{O}_{4} \mathrm{NPs}$ at a dosage of $10 \mathrm{mg} / \mathrm{kg}$, hyaline casts are seen (arrow point) Alcian blue staining. (40× magnification). 


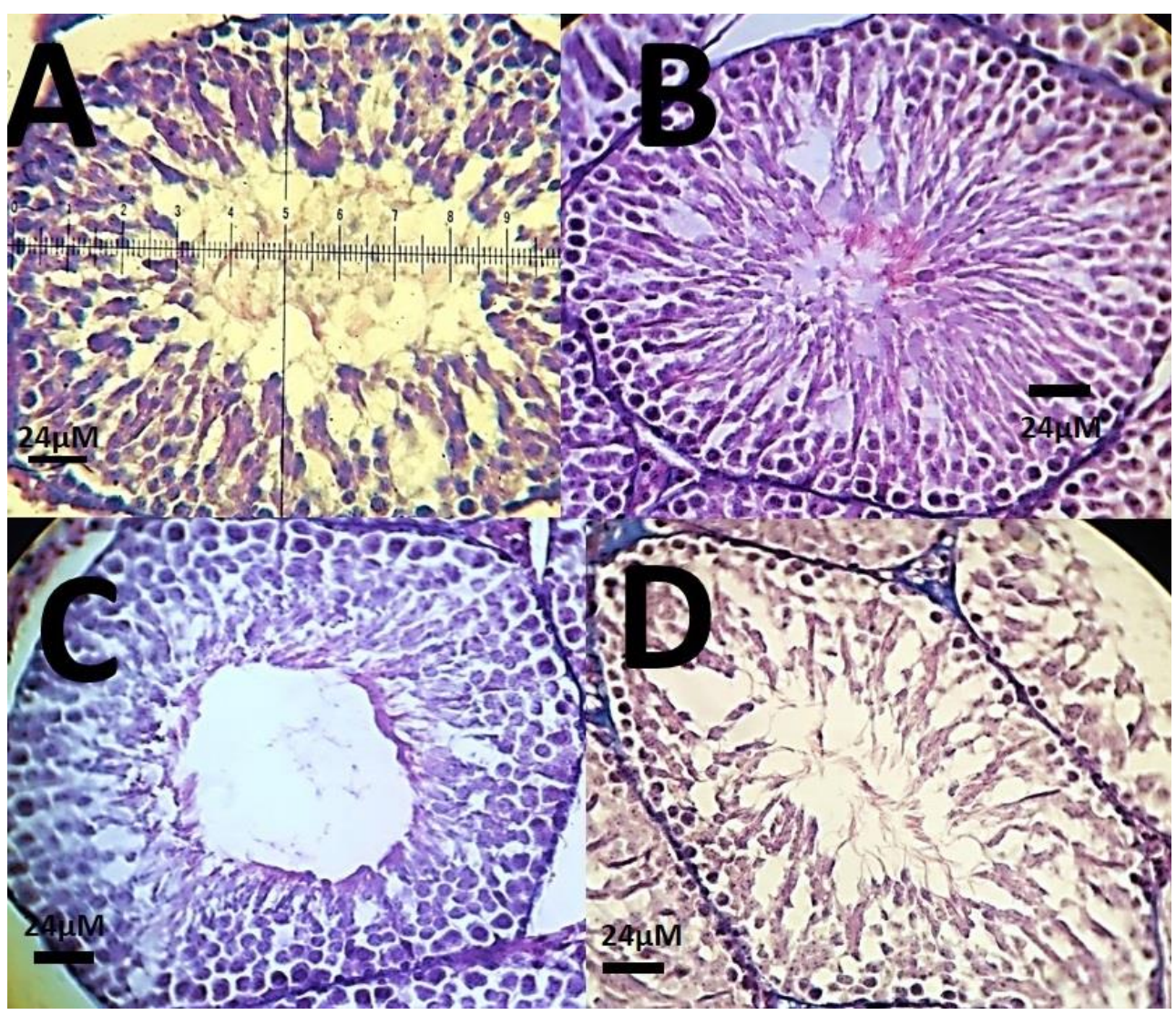

Figure 13. (A): Testis histological pattern of a rat showing normal testicular histopathology and normal seminiferous tubules through Periodic acid-Schiff (PAS) staining $(\times 40)$; (B): PAS-stained histology section of a rat treated with $\mathrm{SnFe}_{2} \mathrm{O}_{4} \mathrm{NPs}$ at a dosage of $0.1 \mathrm{mg} / \mathrm{kg}$ with normal testis appearance following periodic acid-Schiff staining; (C): Testis of a rat treated with $\mathrm{SnFe}_{2} \mathrm{O}_{4} \mathrm{NPs}$ at a dosage of $1 \mathrm{mg} / \mathrm{kg}$ after (arrow point). (D): A testis PAS-stained section of a rat treated with $\mathrm{SnFe}_{2} \mathrm{O}_{4} \mathrm{NPs}$ at a dosage of $10 \mathrm{mg} / \mathrm{kg}$, no obvious sign of inflammation and necrosis is present. PAS staining $(\times 40)$. 


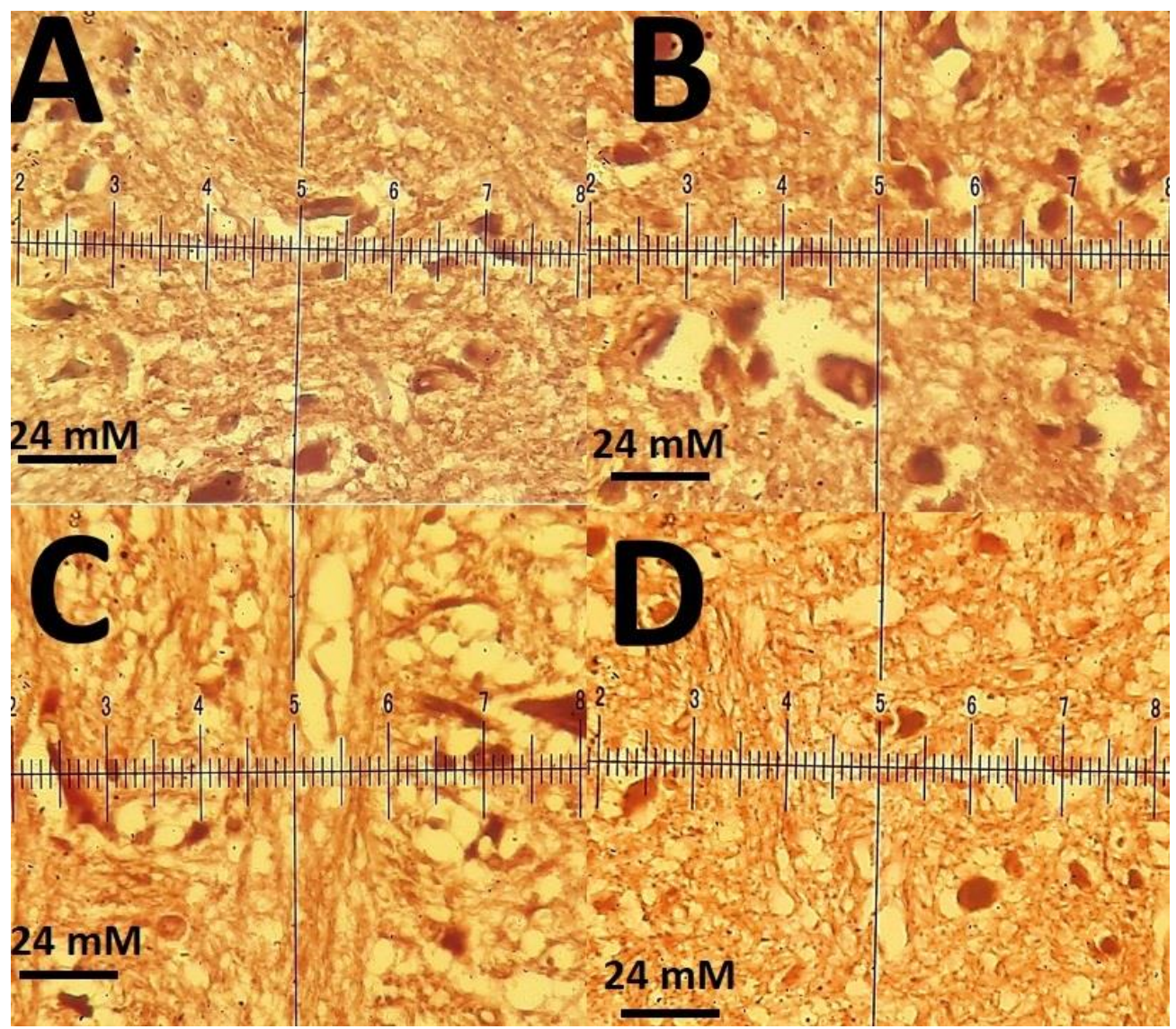

Figure 14. (A): Brain histological pattern of a rat showing normal brain histopathology. trichrome mason staining $(\times 40)$; (B): trichrome Mason-stained histology section of a rat treated with $\mathrm{SnFe}_{2} \mathrm{O}_{4}$ NPs at a dosage of $0.1 \mathrm{mg} / \mathrm{kg}$ with normal brain histology following trichrome mason staining; (C): Brain of a rat treated with $1 \mathrm{mg} / \mathrm{kg} \mathrm{SnFe}_{2} \mathrm{O}_{4} \mathrm{NPs}$ (arrow point). (D): A brain trichrome mason-stained section of a rat treated with $\mathrm{SnFe}_{2} \mathrm{O}_{4} \mathrm{NPs}$ at a dosage of $10 \mathrm{mg} / \mathrm{kg}$, no obvious sign of inflammation and necrosis is present. PAS-staining $(\times 40)$.

\section{Discussion}

By performing in vitro experiments, we examined the sensitivity of two non-cancerous cell lines, derived from the human umbilical vein and human embryonic kidney, towards newly synthesized $\mathrm{SnFe}_{2} \mathrm{O}_{4}$ NPs. We found that HUVECs were more resistant to $\mathrm{SnFe}_{2} \mathrm{O}_{4}$ NPs as compared with HEK293 cells. These findings suggest that the cytotoxicity of the developed $\mathrm{SnFe}_{2} \mathrm{O}_{4} \mathrm{NPs}$ may be tissue-specific. In our study, in agreement with the MTT assay results, severe histopathological changes were observed in the kidneys of rats receiving $\mathrm{SnFe}_{2} \mathrm{O}_{4} \mathrm{NPs}$. On the other hand, $\mathrm{SnFe}_{2} \mathrm{O}_{4} \mathrm{NPs}$ induced a marked decrease in the number of living A459 lung cancer cells. This is in agreement with the detection of Lee et al., reporting that sonicated $\mathrm{SnFe}_{2} \mathrm{O}_{4}$ nanocrystals profoundly enhanced ROS production via the Fenton reaction and exerted significant cytotoxic effects against lung cancer cells [8]. Moreover, they observed no marked cytotoxicity for the normal lung fibroblasts, which is consistent with our findings.

Interesting results were also reported for other metal oxide-based nanoparticles in the recent literature. Zhou and co-workers reported that treatment of A549 cells with monodispersed $\mathrm{Fe}_{2} \mathrm{O}_{3}$ nanoparticles did not affect cell growth and morphology [15]. Ramalingam et al. showed that $\mathrm{Fe}_{2} \mathrm{O}_{3}$ NPs inhibited the proliferation of PA-1 ovarian cancer cell line (IC50 $=120 \mu \mathrm{g} / \mathrm{mL}$ after $24 \mathrm{~h}$ ) [16]. Zerboni and colleagues reported a significant concentration-dependent decrease in the number of viable A549 cells after $24 \mathrm{~h}$ and $48 \mathrm{~h}$ exposed to $\mathrm{CuO}$ NPs at concentrations of 15,20 , and $25 \mu \mathrm{g} / \mathrm{mL}$. In contrast, $\mathrm{ZnO}$ NPs were not able to induce such cytotoxic effects at concentrations less than $25 \mu \mathrm{g} / \mathrm{mL}$ [17]. Li et al. 
showed that low concentrations of iron oxide-based magnetic NPs markedly diminished the cell viability of A549 cells and exerted noticeable synergistic effects against malignant cells [18]. Ghasemi et al. examined the effects of superparamagnetic iron oxide NPs on the viability of HEK293 normal human cells. After 24 h, they observed marked inhibitory effects started at $25 \mu \mathrm{g} / \mathrm{mL}$ (with $6 \%$ decrease in cell viability of HEK293 cells compared with untreated cells) and increased at $200 \mu \mathrm{g} / \mathrm{mL}$ (with $33.7 \%$ decrease in cell viability of HEK293 cells compared with untreated cells [19].

In contrast with these findings, after $24 \mathrm{~h}$ of exposure, our synthesized $\mathrm{SnFe}_{2} \mathrm{O}_{4} \mathrm{NPs}$ induced cytotoxic effects against A549 lung cancer cells in concentrations higher than $100 \mu \mathrm{g} / \mathrm{mL}$ while inducing mild cytotoxicity on HEK293 cells at concentrations higher than $400 \mu \mathrm{g} / \mathrm{mL}$ in a given period. We found no cytotoxic effects for $\mathrm{SnFe}_{2} \mathrm{O}_{4} \mathrm{NPs}$ in non-malignant cells derived from endothelial cells of the human umbilical vein. Future in vitro experiments using different normal and cancer cells are needed to confirm these early findings and further support the application of these newly developed $\mathrm{SnFe}_{2} \mathrm{O}_{4} \mathrm{NPs}$ in theranostics.

In vivo toxicity of nanomaterials is another point of concern deserving careful investigation. In recent years, metal oxide NPs have been synthesized for medical engineering purposes, such as magnetite NPs, zinc oxide NPs, and cerium oxide NPs [20-22]. Despite the wide range of metal oxide NPs, there is a relative paucity of data about the potential side effects of these nanomaterials. Previous studies conducted on laboratory animals have shown the potential nephrotoxic and hepatotoxic effects of high doses of metal oxide NPs. On the other hand, some studies demonstrated that metal oxide NPs at the proper dose could have low mammalian toxicity [23]. In a previous study, the intraperitoneal administration of Xanthan gum-stabilized cerium oxide nanoparticles caused a noteworthy increment in serum antioxidant enzyme activities [24]. It seems that the time and the duration of NP administration could affect the potential toxicity of metal oxide NPs.

$\mathrm{SnFe}_{2} \mathrm{O}_{4} \mathrm{NPs}$ have diverse medical, biomedical, and industrial applications. The unique physicochemical properties of $\mathrm{SnFe}_{2} \mathrm{O}_{4}$ NPs make them excellent candidates for medical engineering and diagnostic imaging. Previous studies conducted on cluttered cell lines have shown that $\mathrm{SnFe}_{2} \mathrm{O}_{4}$ NPs could induce heterogeneous Fenton reaction in the cytoplasmic reticulum, suggesting the possible cytotoxic effect of these nanoparticles on cancer cell lines [8]. In heterogeneous Fenton reaction, the Fenton catalyst converts $\mathrm{H}_{2} \mathrm{O}_{2}$ into free radicals that enhance free radicals in colon cancer cells. Our results showed that $\mathrm{SnFe}_{2} \mathrm{O}_{4} \mathrm{NPs}$ could increase serum oxidative stress markers. It was reported that the catalase modulation of heterogeneous Fenton reaction plays a significant character in achieving selective cancer cell eradication [25].

Interestingly, there is no data regarding the biological effects of $\mathrm{SnFe}_{2} \mathrm{O}_{4} \mathrm{NPs}$ on laboratory animals such as rats, mice, or rabbits. The biochemical data showed the possible nephrotoxicity of the high dose of $\mathrm{SnFe}_{2} \mathrm{O}_{4} \mathrm{NPs}$, confirmed by the histopathological investigation. The histopathological examination of testis histological sections showed no signs of reproductive toxicity. The brain histological investigation also showed no prominent toxic effects on brain tissue. These results lead us to hypothesize that $\mathrm{SnFe}_{2} \mathrm{O}_{4}$ NPs are not able to cross the blood-brain barrier that separates the brain from the blood [26]. Such an explanation can also be proposed for testis histology results because there is a physiological barrier in the testes, which prevents the entry of exogenous compounds, called the testis-blood barrier [27]. In the current work, the high dose of $\mathrm{SnFe}_{2} \mathrm{O}_{4} \mathrm{NPs}$ caused no elevation in serum liver enzymes, while in histology investigation, some signs of slight liver damage were present. Therefore, this suggests that $\mathrm{SnFe}_{2} \mathrm{O}_{4} \mathrm{NPs}$ could have hepatotoxic potential, especially at high doses or in the long-term duration.

In addition to $\mathrm{SnFe}_{2} \mathrm{O}_{4} \mathrm{NPs}$, other NP-based delivery systems were recently synthesized and evaluated using oxides or polymers for theranostics and other medical applications. The unique physical characteristics of supermagnetic NPs have made them promising tools to be used in drug delivery and diagnostic imaging. In this regard, temperature responsive core/shell $\mathrm{Fe}_{3} \mathrm{O}_{4}$ NPs were developed and functionalized with biocompatible 
copolymers [27]. Moreover, Multi-element ferrite NPs acting as heat agents were also synthesized to be used in magnetic hyperthermia treatments for breast cancer therapy [28]. Multi-anchored glycoconjugate-functionalized magnetic NPs were also synthesized for selective killing of bacteria by using an alternate magnetic field [29].

This research work provides an inclusive survey of development of tin ferrite NPs through hydrothermal method for potential application in biomedicine. Future studies will be addressed to optimize $\mathrm{SnFe}_{2} \mathrm{O}_{4} \mathrm{NPs}$ for further minimizing toxicity against non-cancerous cells, and to evaluate in vivo and in vitro toxicity of $\mathrm{SnFe}_{2} \mathrm{O}_{4} \mathrm{NPs}$ on different organs.

\section{Conclusions}

Magnetic NPs offer a wide variety of applications. In the current study, a hydrothermal approach is utilized for the synthesis of $\mathrm{SnFe}_{2} \mathrm{O}_{4}$ NPs. The synthesized NPs are analyzed exploiting FTIR, UV-Vis, XRD, and SEM techniques. The results obtained show that the $\mathrm{SnFe}_{2} \mathrm{O}_{4}$ are roughly spherical in shape with sizes ranging from 15 to $50 \mathrm{~nm}$. The synthesized $\mathrm{SnFe}_{2} \mathrm{O}_{4}$ NPs have shown a favorable non-cytotoxic effect on HUVEC cells while exerting a time- and dosage-dependent cytotoxicity on human lung cancer cells. It is of great importance that these NPs did not elicit any cytotoxic effects on human umbilical vein endothelial cells. The in vivo results suggested that $\mathrm{SnFe}_{2} \mathrm{O}_{4} \mathrm{NPs}_{\text {could }}$ have a nephrotoxic potential but could be safe at low doses and, possibly, in the short term. Specifically, the in vivo experiments showed that $\mathrm{SnFe}_{2} \mathrm{O}_{4} \mathrm{NPs}$ at high doses could have toxic effects on the lung, liver, and kidney of rats. In contrast, there were no effects on the brain and testis histopathology. These results suggest that $\mathrm{SnFe}_{2} \mathrm{O}_{4} \mathrm{NPs}$ are not able to cross blood-brain barrier and blood-testis barrier. In order to propose the use of these NPs in theranostics, evaluating their possible impacts on human and rodent cells derived from other tissues appears warranted.

Author Contributions: Conceptualization, A.R.; methodology, S.S., M.R.H., A.R., M.N.Z. and A.A.; investigation, S.S., M.R.H., A.R., M.N.Z. and A.A.; resources, S.S., M.R.H., A.R., M.N.Z., A.A. and F.B.; writing—original draft preparation, S.S., M.R.H., A.R., M.N.Z. and A.A.; writing-review and editing, F.B.; supervision, A.R., M.N.Z.; funding acquisition, A.R., M.N.Z. and F.B. All authors have read and agreed to the published version of the manuscript.

Funding: This study received funding from the Higher Education Commission of Pakistan (NRPU Project. 6515/Punjab/NRPU/R\&D/HEC/2016).

Institutional Review Board Statement: The study was conducted according to the guidelines of the Declaration of Helsinki and approved by the Ethics Committee of Faculty of Veterinary Medicine, University of Zabol (IR.UOZ.REC.1399.009).

Informed Consent Statement: Not applicable.

Data Availability Statement: Data are included within this article.

Acknowledgments: M.N. Zafar acknowledges funding from Higher Education Commission of Pakistan (NRPU Project. 6515/Punjab/NRPU/R\&D/HEC/2016).

Conflicts of Interest: The authors declare no conflict of interest.

\section{References}

1. Farokhzad, O.C.; Langer, R. Nanomedicine: Developing smarter therapeutic and diagnostic modalities. Adv. Drug Deliv. Rev. 2006, 58, 1456-1459. [CrossRef]

2. Zhang, L.; Gu, F.; Chan, J.; Wang, A.; Langer, R.; Farokhzad, O. Nanoparticles in Medicine: Therapeutic Applications and Developments. Clin. Pharmacol. Ther. 2008, 83, 761-769. [CrossRef]

3. Ranji-Burachaloo, H.; Gurr, P.A.; Dunstan, D.E.; Qiao, G.G. Cancer Treatment through Nanoparticle-Facilitated Fenton Reaction. ACS Nano 2018, 12, 11819-11837. [CrossRef] 
4. Etminan, M.; Nabiyouni, G.; Ghanbari, D. Preparation of tin ferrite-tin oxide by hydrothermal, precipitation and auto-combustion: Photo-catalyst and magnetic nanocomposites for degradation of toxic azo-dyes. J. Mater. Sci. Mater. Electron. 2018, 29, 1766-1776. [CrossRef]

5. Ahmad, I.; Shah, S.M.; Zafar, M.N.; Ullah, S.; Ul-Hamid, A.; Ashiq, M.N.; Jabeen, U.; Shafa, M.; Rahdar, A. Fabrication of highly resistive La-Zn co-substituted spinel strontium nanoferrites for high frequency devices applications. Mater. Chem. Phys. 2021, 259, 124031. [CrossRef]

6. Lafta, S.H. Effect of $\mathrm{pH}$ on Structural, Magnetic and FMR Properties of Hydrothermally Prepared Nano Ni Ferrite. Open Chem. 2017, 15, 53-60. [CrossRef]

7. Zhang, Z.; Liu, Y.; Yao, G.; Zu, G.; Hao, Y. Synthesis and Characterization of $\mathrm{NiFe}_{2} \mathrm{O}_{4}$ Nanoparticles via Solid-State Reaction. Int. J. Appl. Ceram. Technol. 2013, 10, 142-149. [CrossRef]

8. Lee, K.-T.; Lu, Y.-J.; Mi, F.-L.; Burnouf, T.; Wei, Y.-T.; Chiu, S.-C.; Chuang, E.-Y.; Lu, S.-Y. Catalase-Modulated Heterogeneous Fenton Reaction for Selective Cancer Cell Eradication: $\mathrm{SnFe}_{2} \mathrm{O}_{4}$ Nanocrystals as an Effective Reagent for Treating Lung Cancer Cells. ACS Appl. Mater. Interfaces. 2017, 9, 1273-1279. [CrossRef]

9. Agarwal, H.; Nakara, A.; Shanmugam, V.K. Anti-inflammatory mechanism of various metal and metal oxide nanoparticles synthesized using plant extracts: A review. Biomed. Pharmacother. 2019, 109, 2561-2572. [CrossRef]

10. Liu, W.; Zeb, A.; Lian, J.; Wu, J.; Xiong, H.; Tang, J.; Zheng, S. Interactions of metal-based nanoparticles (MBNPs) and metal-oxide nanoparticles (MONPs) with crop plants: A critical review of research progress and prospects. Environ. Rev. 2020, 28, 294-310. [CrossRef]

11. Elmoussaoui, H.; Hamedoun, M.; Mounkachi, O.; Benyoussef, A.; Masrour, R.; Hlil, E.K. New results on Magnetic Properties of Tin-Ferrite Nanoparticles. J. Supercond. Nov. Magn. 2012, 25, 1995-2002. [CrossRef]

12. Sargazi, S.; Saravani, R.; Reza, J.Z.; Jaliani, H.Z.; Galavi, H.; Moudi, M.; Abtahi, N.A. Novel poly (adenosine di-phosphate-ribose) polymerase (PARP) inhibitor, AZD2461, down-regulates VEGF and induces apoptosis in prostate cancer cells. Iran Biomed. J. 2019, 23, 312-323. [PubMed]

13. Mosmann, T. Rapid colorimetric assay for cellular growth and survival: Application to proliferation and cyto-toxicity assays. $J$. Immunol. Methods 1983, 65, 55-63. [CrossRef]

14. Ohkawa, H.; Ohishi, N.; Yagi, K. Assay for lipid peroxides in animal tissues by thiobarbituric acid reaction. Anal. Biochem. 1979, 95, 351-358. [CrossRef]

15. Zhou, H.; Xiao, L.; Luo, Y.; Chen, J.H.; Xu, J.H.; Zeng, Y.; Zhong, M.Z. Facile synthesis of monodispersed Fe $\mathrm{O}_{3} \mathrm{O}_{3}$ nanoparticles and its cellular uptake and cytotoxicity studies. J. Nanosci. Nanotechnol. 2013, 136, 560-6565.

16. Ramalingam, V.; Harshavardhan, M.; Dinesh Kumar, S.; Malathi devi, S. Wet chemical mediated hematite $\alpha-\mathrm{Fe}_{2} \mathrm{O}_{3}$ nanoparticles synthesis: Preparation, characterization and anticancer activity against human meta-static ovarian cancer. J. Alloys Compd. 2020, 834, 155118. [CrossRef]

17. Zerboni, A.; Bengalli, R.; Baeri, G.; Fiandra, L.; Catelani, T.; Mantecca, P. Mixture Effects of Diesel Exhaust and Metal Oxide Nanoparticles in Human Lung A549 Cells. Nanomaterials 2019, 9, 1302. [CrossRef] [PubMed]

18. Li, W.; Yu, H.; Ding, D.; Chen, Z.; Wang, Y.; Wang, S.; Li, X.; Keidar, M.; Zhang, W. Cold atmospheric plasma and iron oxide-based magnetic nanoparticles for synergetic lung cancer therapy. Free. Radic. Biol. Med. 2019, 130, 71-81. [CrossRef]

19. Ghasemi, A.; Jafari, S.; Saeidi, J.; Mohtashami, M.; Salehi, I. Synthesis and characterization of polyglycerol coated superparamagnetic iron oxide nanoparticles and cytotoxicity evaluation on normal human cell lines. Colloids Surf. A Physicochem. Eng. Asp. 2018, 551, 128-136. [CrossRef]

20. Aliahmad, M.; Rahdar, A.; Sadeghfar, F.; Bagheri, S.; Hajinezhad, M.R. Synthesis and Biochemical effects of magnetite nanoparticle by surfactant-free electrochemical method in an aqueous system: The current density effect. Nanomed. Res. J. 2016, 1, 39-46.

21. Rahdar, A.; Hajinezhad, M.R.; Sivasankarapillai, V.S.; Askari, F.; Noura, M.; Kyzas, G.Z. Synthesis, characteriza-tion, and intraperitoneal biochemical studies of zinc oxide nanoparticles in Rattus norvegicus. Appl. Phys. A 2020, 126, 347. [CrossRef]

22. Sadidi, H.; Hooshmand, S.; Ahmadabadi, A.; Hosseini, S.J.; Baino, F.; Vatanpour, M.; Kargozar, S. Cerium Oxide Nanoparticles (Nanoceria): Hopes in Soft Tissue Engineering. Molecules 2020, 25, 4559. [CrossRef]

23. Taimoory, S.M.; Rahdar, A.; Aliahmad, M.; Sadeghfar, F.; Hajinezhad, M.R.; Jahantigh, M.; Shahbazi, P.; Trant, J.F. The synthesis and characterization of a magnetite nanoparticle with potent antibacterial activity and low mammalian toxicity. J. Mol. Liq. 2018, 265, 96-104. [CrossRef]

24. Rahdar, A.; Aliahmad, M.; Hajinezhad, M.R.; Samani, M. Xanthan gum-stabilized nano-ceria: Green chemistry based synthesis, characterization, study of biochemical alterations induced by intraperitoneal doses of nano-particles in rat. J. Mol. Struc. 2018, 1173, 166-172. [CrossRef]

25. Sweeney, M.D.; Zhao, Z.; Montagne, A.; Nelson, A.R.; Zlokovic, B.V. Blood-Brain Barrier: From Physiology to Disease and Back. Physiol. Rev. 2019, 99, 21-78. [CrossRef]

26. Gao, Y.; Mruk, D.; Chen, H.; Lui, W.; Lee, W.M.; Cheng, C.Y. Regulation of the blood-testis barrier by a local axis in the testis: Role of laminin $\alpha 2$ in the basement membrane. FASEB J. 2017, 31, 584-597. [CrossRef]

27. Al Dine, E.J.; Ferjaoui, Z.; Ghanbaja, J.; Roques-Carmes, T.; Meftah, A.; Hamieh, T.; Toufaily, J.; Schneider, R.; Marchal, S.; Gaffet, E.; et al. Thermo-responsive magnetic $\mathrm{Fe}_{3} \mathrm{O}_{4} @ \mathrm{P}$ (MEO2MAX-OEGMA100-X and their applications as drug delivery systems. Int. J. Pharm. 2017, 532, 738-747. [CrossRef] 
28. Oshima, A.; Kanda, K.; Fujiwara, K.; Ide, T.; Takano-Kasuya, M.; Ichiyanagi, Y. PEGylation of Co-Zn Ferrite Nanoparticles for Theranostics. J. Nanosci. Nanotechnol. 2020, 20, 7255-7262. [CrossRef]

29. Raval, Y.S.; Fellows, B.D.; Murbach, J.; Cordeau, Y.; Mefford, O.T.; Tzeng, T.R. Multianchored Glycoconjugate-Functionalized Magnetic Nanoparticles: A Tool for Selective Killing of Targeted Bacteria via Alternating Magnetic Fields. Adv. Funct. Mater. 2017, 27, 1701473. [CrossRef] 